\title{
Large square baling and bale handling efficiency-A case study
}

\author{
Benjamin Kemmerer, Jude Liu* \\ Department of Agricultural and Biological Engineering, The Pennsylvania State University, University Park, USA; \\ "Corresponding Author: jliu@engr.psu.edu
}

Received 12 November 2011; revised 24 December 2011; accepted 29 January 2012

\begin{abstract}
Large square baling is currently recognized as a high efficiency biomass harvesting system. Baling, bale collecting, and storing at a commercial wheat straw farm was studied as a typical large square bale harvesting system. Factors that affect large square bale production and handling logistics were quantified. Field operations of a large square baler, two bale handlers, and three bale trucks were observed in a full day field operation. System performance was analyzed and material capacities of all machines used in this system were determined based on field measurements. System limitations were quantified, and means to increase system efficiency or reduce production costs were discussed. Results showed that $\mathbf{3 4 0}$ wheat straw bales at a density of $116 \mathrm{~kg} \cdot \mathrm{m}^{-3}$ (wet matter) were made with a single large square baler during $8 \mathrm{~h}$ field operations. The number of bales produced was the system limitation when one baler, two bale handlers and three bale trucks were used. Adding a baler or reduce the number of operators can increase system efficiency. The large square baler used in this study had a material capacity of $13 \mathrm{Mg} \cdot \mathrm{h}^{-1}$. Similar baling trials were conducted in a switchgrass field and results indicated that the baler had the same material capacity.
\end{abstract}

Keywords: Biomass; Logistics; Material Capacity; Harvest

\section{INTRODUCTION}

Energy crops and agricultural crop residues hold great potential for bioenergy. Traditional agricultural harvest and handling systems and facilities are currently used for handling biomass. However, high cost is still a main roadblock of supplying biomass feedstocks. For harvesting, transporting, and storing herbaceous biomass, large square bales have many advantages over small square bale and round bale counterparts as well as other possible harvest methods. The advantage of round bales is their ability to shed rain water when properly stored outdoors. However, the shape of the round bale makes handling, transportation, and storage of the bale inefficient compared to a large square bale. The advantages of large square bales stem from the high capacity of large square balers and both storage and transportation characteristics of the bales. Field equipment, transportation, and storage facilities for large square bales in agricultural markets already exist. Large square balers that currently accommodate forage crop harvest can be readily utilized in biomass harvest [1]. Biomass in the form of large square bales has already been employed in co-firing plants to produce electricity [2]. Biomass large square bales are also a viable cellulosic feedstock for future bioenergy production. Currently, the largest challenge in biomass logistics is to reduce the high cost associated with field operations. Thus, thoroughly understanding the capacity of current harvest and handling equipment is essential for optimizing biomass production systems.

Large square bales are increasing in popularity across the United States due to recent advances in large square baling technology. Large square balers produce a bale that is as large as $1.2 \mathrm{~m} \times 1.2 \mathrm{~m} \times 2.4 \mathrm{~m}$ in size. Models that produce smaller square bales have the ability to produce a denser bale [1]. Cundiff and Marsh [3] found that large square bale densities of $200 \mathrm{~kg} \cdot \mathrm{m}^{-3}$ can be achieved with modern large square balers. This value is considerably higher than the density they were able to achieve with a round baler, which was around $140 \mathrm{~kg} \cdot \mathrm{m}^{-3}$. Large square bales have been shown to harvest crops cheaper then round balers on a per dry Mg basis [3]. Although the shape of the square bale has many advantages over round bales, large square bales cannot be stored outside in wet climates unless wrapped in a plastic film or tarped. When stored properly, large square bales preserve the crop better than round bales [4]. The other downside to large square balers is a high initial equipment cost as compared to round balers. 
Baling involves a multiple-pass system. Because the biomass must be left in the field to dry to desirable moisture content, mowing is typically accomplished with a machine that also conditions the crop by cracking the stems to reduce the field drying time. Following mowing, a rake is used to gather the crop into a swath that not only helps to facilitate drying, but windrows the crop so that it can be picked up by the baler. Balers are implements that are pulled behind a tractor in the field. Bale collection is typically performed by loading the bales onto a flatbed truck with a front-end bale grabber. Automatic bale collectors for large square bales are also available and have the advantage of being able to both retrieve and stack the large square bales.

Sokhansanj [1] has quantified the cost of various forms of transportation for biomass feedstocks. Similarly, Kumar and Ileleji [5] have quantified the handling and storage costs for large square bales at a bioenergy plant. However, in both of these evaluations the details of field operations and field capacities of machines involved in the field harvesting and handling were not available [6]. Instead, costs of bales at the farm gate were used to analyze bioenergy production costs. To optimize field machine systems so as to achieve the highest system efficiency or productivity, farm managers or biomass logistics professionals need to know the field efficiency of each machine involved in baling and bale handling. In addition, quantitatively understanding the capacity of biomass harvest machines is essential to assess daily production and supply rate for a biorefinery plant or a storage facility.

The goal of this research is to quantify the field performance parameters associated with large square bale production and handling. The objectives associated with this goal were 1) to quantify the material capacities of machines producing and handling large square bales on a commercial scale; and 2) to determine system performance and system limitations of large square bale production.

\section{MATERIALS AND METHODS}

\subsection{Description of the Farm}

Jaindl Farms in Allentown, Pennsylvania raises approximately 750,000 turkeys every year. Four thousand hectares of crop land are used to grow the raw materials needed to feed and maintain the livestock raised on the farm. The farm uses a large square baler to bale wheat straw left in the fields after grain harvest in early July. The large square bales of straw are used for bedding in the turkey houses. Because of the wet climate in Pennsylvania, all of the bales must be collected after baling and stored under roof in a timely fashion to prevent rain from dampening the bales. Therefore, this farm was chosen to study the field efficiencies of this logistics system of handling large square bales.

Jaindl Farms bales and stores around 650 ha of wheat straw per year, producing 4600 to 4800 bales that measure $0.9 \times 1.2 \times 2.44 \mathrm{~m}$. Most of the baling is done in fields that range from 20 to 60 ha in size. All the bales need to be transported several kilometers, depending on the field location, for storage. Fifteen to thirty days are necessary from the time bale production starts until all the bales are stored under roof. The number of days needed to perform these operations is largely depended on weather conditions. If little or no rain falls in early July, all operations can be completed in as fast as two weeks.

\subsection{Field Equipment}

The equipment used in bale production, bale handling, and in-field transportation was determined by the landowner to be the most efficient for their particular situation. Figure 1 shows the large square baler, bale handler, and the flatbed bale truck. The straw was all raked with a Kuhn twin rotary rake model GA 6002. The rake was used to form uniform and evenly spaced windrows from the straw that had been expelled by the combines. If the straw was rained on before baling, the rake was also needed to fluff the straw so that it would dry properly. The swath the rake covered was adjustable. The operator adjusted the swath of the rake in order to form windrows of proper size. The maximum swath or working width of the rake was 5.8 meters. The rake was pulled by a John Deere 7820 tractor that had $115.6 \mathrm{~kW}$ PTO power. The rake requires a minimum of $30 \mathrm{~kW}$ PTO power. The tractor used to power the rake was extensively oversized. The oversized tractor was used due to availability. A

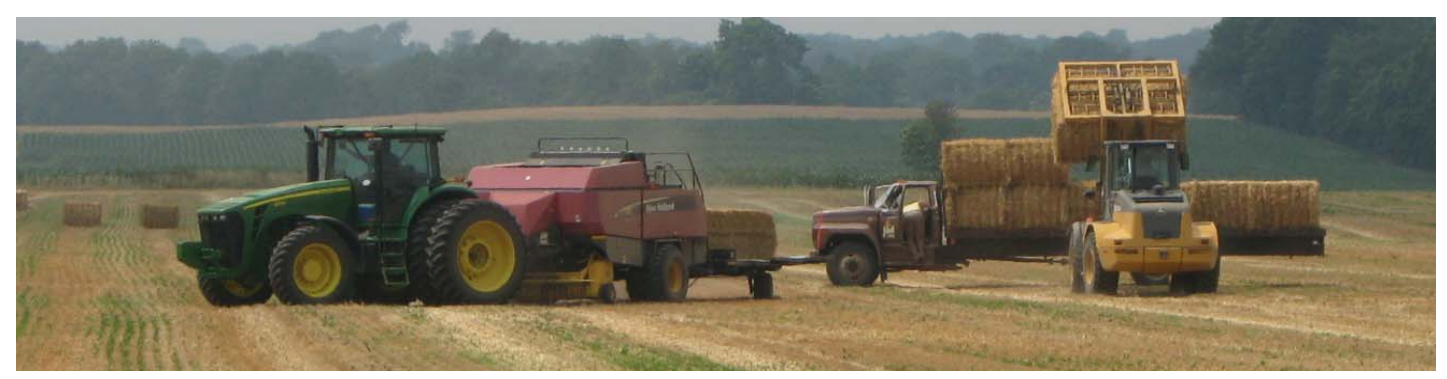

Figure 1. The large square baler, bale handler, and bale truck used in straw harvesting. 
smaller tractor may add capital costs; but it would greatly improve fuel efficiency.

A New Holland model BB960A large square baler was used to bale all 650 ha of wheat straw. A John Deere 8330 tractor with $168 \mathrm{~kW}$ PTO power was used to run the baler. The baler required a minimum of $90 \mathrm{~kW}$ of PTO power. However the extra power and weight of the tractor were necessary to properly handle the baler on fields with steep inclines. The baler was fitted with a Hoelscher bale accumulator that trailed behind the baler. The bale accumulator accumulated two large square bales at the back to the bale chamber and simultaneously dumped these bales onto the ground in a parallel configuration. The accumulator was hydraulically powered by the tractor that added slightly to the power requirements of the baler. The baler was typically operated from 11:00 am to 7:00 pm. When weather conditions were optimal, a maximum of 350 bales could be produced in a day. Time restrictions on baling were based on the dew burning off in the morning and setting in the night.

A compact wheel loader was used to load the bales onto trucks with $2.44 \mathrm{~m}$ by $7.32 \mathrm{~m}$ flatbeds. All loading was performed in the field. Unloading at the storage facility was preformed with a second wheel loader. The wheel loaders were fitted with Hoelscher grapples that lift the bale from the top. The grapples, which were matched to the bale accumulator, had the ability to pick up two bales at a time. Three flatbed trucks were used to transport the straw bales back to storage site. This size truck was well suited for the specific farm conditions. The trucks were able to get in and out of the field easily and adequately maneuver around the storage facility. All of the trucks had the same $2.44 \mathrm{~m}$ by $7.32 \mathrm{~m}$ bed and a 17 bale capacity.

All of the bales were moved to a storage facility that was 3 to $8 \mathrm{~km}$ away, depending on the field location. The farm's large square bale handling capabilities accurately portray how switchgrass bales would be collected and transported to a satellite storage facility. Semi trailers would not necessarily be needed to pick bales up at farms and transport them a short distance to a storage facility. The trucks with only a $7.32 \mathrm{~m}$ long bed were able to drive through the field to each set of two bales, eliminating the need to further accumulate the bales. For a storage facility $3 \mathrm{~km}$ away, three trucks carrying 17 bales per load were needed to haul away the bales at the same or greater pace then bales were produced by the baler.

\subsection{Labor}

Field operations included one man operating the baler, two men operating the two wheel loaders and two truck drivers. The baler ran continuously throughout the day with the exception of a lunch break. Since no bales were left out in the field over night, the bales were collected at about the same pace as they were produced. A truck driver would bring the truck into the field and drive up to each set of two bales. The wheel loader operator would follow the truck through the field and load the bales two at a time. When the truck was full the driver would exit the field and head toward the storage facility. The trucks were loaded in an interlocking manner and the bales were not strapped down. Disregarding the straps greatly saved time and increased efficiency. Because there were three drivers and two trucks, a driver was not present while the truck was unloaded. The driver of the fully loaded truck would drive into the storage facility and park the truck to be unloaded. By the time this truck arrived with a full load of straw, the previous truck to arrive at the site would be empty. This process was repeated in a cycle, with minor delays from a driver waiting for a truck to be unloaded.

\section{RESULTS AND DISCUSSION}

\subsection{Results of Wheat Straw Baling}

A 30 ha field of wheat straw harvesting was observed. Entire field operations can be presented in Figure 2. The field yielded $3.20 \mathrm{Mg}$ of straw wet matter biomass per hectare. The field was rectangular shaped with no slopes greater than 3\%. The field was raked, baled, and all the

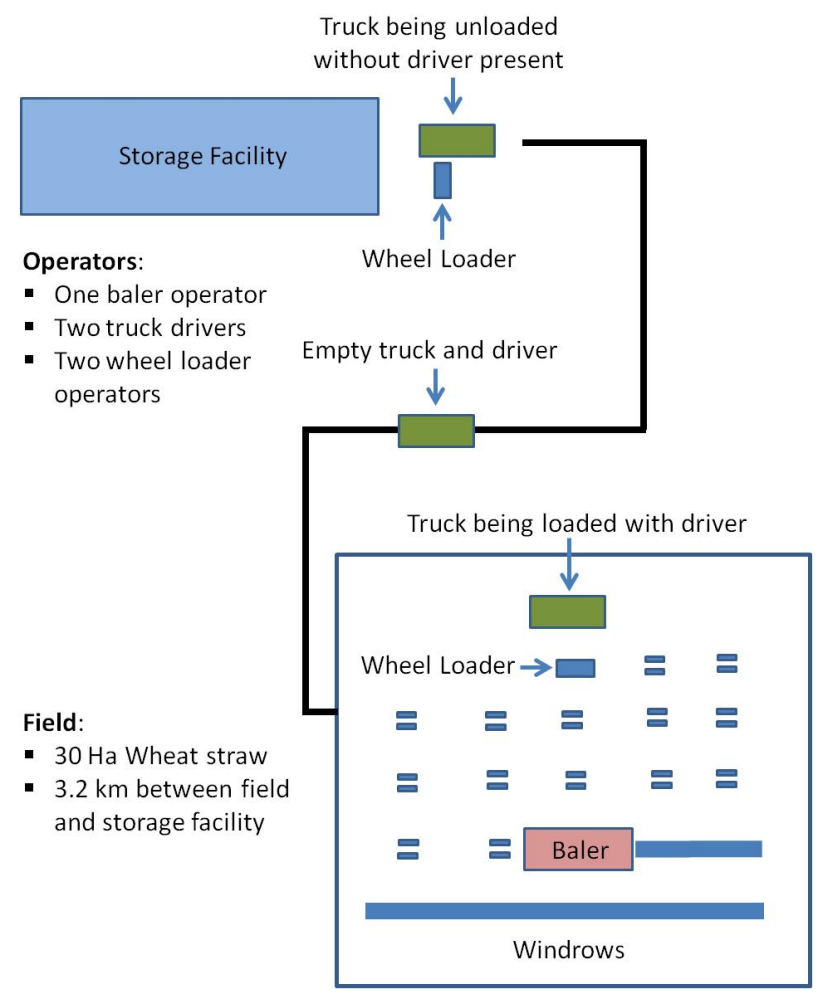

Figure 2. Schematic of field and storage operations. 
bales were put into storage in one day. The field was raked with the twin rotary rake at a field capacity of 8 $\mathrm{ha} \cdot \mathrm{h}^{-1}$. The raking started at 10:30 am and finished in 3.75 hours. The average speed of the rake was $12 \mathrm{~km} \cdot \mathrm{h}^{-1}$ which was a speed chosen based on field conditions. At this rate, the rake was able to process approximately 26 $\mathrm{Mg} \cdot \mathrm{h}^{-1}$ of material. Since the speed at which the rake was operated was independent of yield, the rake can be operated at $12 \mathrm{~km} \cdot \mathrm{h}^{-1}$ for almost any yield.

Baling in the field was started at approximately 11:00 am. The baler was set to produce $2.44 \mathrm{~m}$ long bales that averaged $306 \mathrm{~kg}$ of wet matter. This resulted in an average bale density of $116 \mathrm{~kg} \cdot \mathrm{m}^{-3}$. The bale density was kept low so that the bales would break apart easily to spread for turkey bedding. Increasing the density of straw bales beyond $120 \mathrm{~kg} \cdot \mathrm{m}^{-3}$ would result in higher permanent deformation and cause the straw to cake together. At this low density, 340 bales were produced from this field in approximately $8 \mathrm{~h}$. The actual material capacity of the baler was $13 \mathrm{Mg} \cdot \mathrm{h}^{-1}$ (wet mass) at a ground speed of $11 \mathrm{~km} \cdot \mathrm{h}^{-1}$, resulting in an average of 43 bales per hour.

Loading bales on to trucks was performed in two different ways. If there was not a truck present in the field, the wheel loader operator would accumulate the bales onto stacks. When a truck did arrive, the truck would pull up to the stack and the bales would be loaded. This was to save the number of stops when truck arrived later. If there were trucks available, each truck would drive through the field to each set of two bales left by the baler. The wheel loader would follow and immediately load the bales. When the bales were unloaded into storage the truck was stationary while wheel loader operator drove in and out of a pole barn. Bales were stored in an open ended pole barn. The barn was high enough to stack the bales three layers high. Unloading times varied slightly with how far the bales had to be driven into the storage where they were stacked. Like the wheel loader in the field, the wheel loader at the storage facility was capable of handling two bales at all times.

Material capacity data was recorded of each piece of equipment over the course of approximately nine hours from the time the tractor and rake started to operate in the field at 10:30 am until all bales were placed in storage at 7:30 pm. For comparison purposes all material capacities are presented in terms of bales per hour in Figure 3. Material capacity in terms of tons per hour will be depended on bale density.

Figure 3 shows that the baler had a much lower material capacity than any other operations that took place simultaneously. The bale accumulator attached to the baler and paired with the wheel loader grabbles roughly doubled the pace at which the bales could be loaded and unloaded as compared to handling one bale at a time. This resulted in idle handling equipment at many points throughout the day. The bales could be loaded onto a truck from a stack the fastest but it required that the bales must be accumulated first. The combination of time required to accumulate bales into a stack and then load bales from that accumulation was slower than if the bales were loaded directly onto the trucks without any prior accumulation. Accumulating in the field was most likely preformed to keep the wheel loader and operator from sitting idle when a truck was not present.

Based on the field observation results as shown in Figure 3, the system efficiency could be increased by balancing field capacities of all field machines. Adding a baler would induce capital cost; but it could maximize

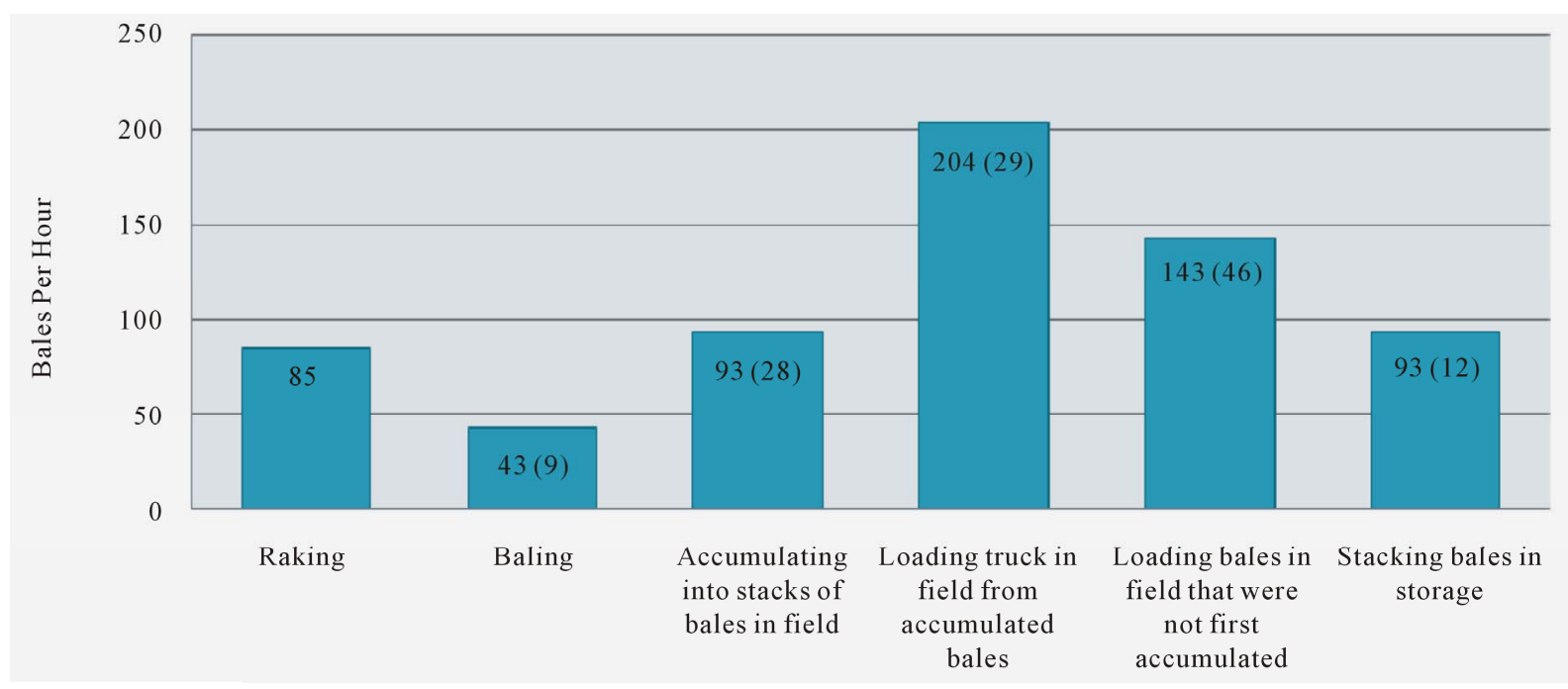

Figure 3. Material capacities in terms of bales per hour for raking, baling, and handling operations (the value in parentheses is the standard deviation of the number of bales; std. dev. is not available for raking as it was calculated by total raking time and total number of bales made). 
the productivity of this systems. Beside baling and raking, stacking bales either in field or in storage would limit the system efficiency. Depending on the distance from the field to storage location, number of bale trucks should be adjusted to avoid idle. For a distance shorter than $8 \mathrm{~km}$, trucks needed approximately 10 minutes round trip time on road. Then the transport capacity of trucks would be $17 \times 6$ which is 102 bales per hour. Therefore, for a one rake and two-baler system, one operator operates both the bale handler and the truck, then drives the truck to the storage and unload the truck would be the best. For example, a system with two trucks, two bale handlers, and two drivers/operators would be the best for baling and storing large bales at an $8 \mathrm{~km}$ travel distance. Doubling the field operation hours of the baler would be equivalent to adding an additional baler.

\subsection{Comparison with Switchgrass Baling}

Switchgrass baling test was conducted in a switchgrass seed farm [7]. New Holland BB9080 large square baler was used. The switchgrass field was approximately 10 ha in size with an average yield of $2.42 \mathrm{Mg} \cdot \mathrm{ha}^{-1}$. The moisture content was $12.5 \%$ (w.b.) at time of harvest.

While the wheat field was significantly larger than the switchgrass field, many field conditions that could affect baler performance were similar. Windrows in both fields were approximately $610 \mathrm{~m}$ in length. Thus, equipment in both fields spending equal amount of time per windrow operating in the headlands. In addition, both the switchgrass and the wheat fields did not contain any slopes greater than 3\%. Both fields yielded a similar amount of wet matter biomass with the switchgrass field at 3.53 $\mathrm{Mg} \cdot \mathrm{ha}^{-1}$ and wheat straw field at $3.20 \mathrm{Mg} \cdot \mathrm{ha}^{-1}$. The large square balers used in both studies were New Holland Models that made bales with a $0.9 \times 1.2 \mathrm{~m}$ end section. The bales at both farms were made at the same length. The baler used in the switchgrass study was a slightly newer model than the baler used in the switchgrass baling study but they mechanically function exactly the same.
The switchgrass baling test focused only on the aspect of switchgrass large square bale logistics. The only major difference between bales produced in the switchgrass field was bale density. The switchgrass does not have exactly the same biological properties as the straw but they have many similarities. The similarities between the switchgrass and straw are evident in the fact that both balers had an average material capacity of approximately $13 \mathrm{Mg} \cdot \mathrm{h}^{-1}$ (wet) for each material. By using the densities of the bales to convert material capacity in bales per hour into $\mathrm{Mg} \cdot \mathrm{ha}^{-1}$ for each operation, the rate at which the switchgrass from the large square baler field study can be theoretically gathered, transported, and put into storage was calculated. Table 1 compares these operations for both farms in terms of $\mathrm{Mg} \cdot \mathrm{h}^{-1}$. For the tests in switchgrass field, two windrows or one round trip was treated as one replication. After removing headlines, there were only two replications possible. Heavy rain in the second day stopped the field tests. Thus, those values in Table 1 for switchgrass were calculated using two replications and no standard deviations available.

The rake had constant field capacity of $8 \mathrm{ha} \cdot \mathrm{h}^{-1}$. Therefore the material capacity of the rake increased with an increase in yield in the switchgrass field as compared to the straw field. The maximum material capacity of both balers was $13 \mathrm{Mg} \cdot \mathrm{h}^{-1}$. The baler in the wheat straw field did not create as dense of a switchgrass bale and therefore produced more bales for any given amount of material. The bottom five operations in Table 1 illustrate the increased rate at which the material can be handled due to an increase in bale density. The switchgrass bales were produced $55 \%$ higher density than the straw bales. This would result in a 55\% increase in the rate at which the material from the field could be loaded, transported, and stored. The amount of extra energy used to pick up and transport the heavier bales is marginal. Over the long term, the denser bales would result in roughly a $55 \%$ decrease in fuel consumption and labor to move the same amount of material for each of these five operations.

Table 1. Comparison of material capacities for different operations and densities.

\begin{tabular}{ccc}
\hline Field operation & $\begin{array}{c}\text { Straw bale, } \mathrm{Mg} \cdot \mathrm{h}^{-1} \\
\left(\text { Bale density: } 116 \mathrm{~kg} \cdot \mathrm{m}^{-3} \text { wet matter) }\right.\end{array}$ & $\begin{array}{c}\text { Switchgrass bale, } \mathrm{Mg} \cdot \mathrm{h}^{-1} \\
\left(\text { Bale density: } 180 \mathrm{~kg} \cdot \mathrm{m}^{-3} \mathrm{wet} \mathrm{matter}\right)\end{array}$ \\
\hline Raking & 25.9 & 28.6 \\
Baling & $13.0(2.76)$ & 13.0 \\
Accumulating bales on stacks & $28.5(8.27)$ & 44.0 \\
Loading truck from accumulated bales & $62.4(8.88)$ & 96.7 \\
Loading truck from not first accumulated bales & $43.77(14.09)$ & 67.8 \\
Stacking bales in storage & $28.5(3.67)$ & 44.0 \\
\hline
\end{tabular}




\section{CONCLUSIONS}

The logistics of handling and transporting large square bales and the equipment used were unique in this particular bale production system. It is important to note that the bales could be handled and transported at more than twice the rate at which the bales were produced. This was due in part to the ability of the wheel loaders to handle two bales at a time. If the wheel loaders could only handle one bale at a time, the loading and unloading rates would be $50 \%$ less. The field wheel loader had the most idling time. Based on the pace of bale collection in this field, two balers could be operated at the same time and the wheel loaders would still be able to keep pace with the baler. The addition of another baler would double daily bale production, transportation and storage capacities. Currently a maximum of 340 bales can be handled in one day. A second baler could bring production approximately 700 bales per day.

By comparing material capacities of the machines in both bales per hour and tons per hour, the bale density became significant. Every percent increase in bale density corresponds to a percent increase in the material capacity of the wheel loaders and trucks. Wheat straw bales produced were kept at a low density so that the quality of the straw as a bedding material would not be negatively affected. In a biomass scenario, it would be advantageous to produce bales as dense as possible in order to minimize costs incurred from handling, transportation, and storage.

In both the switchgrass field and the straw field, the balers were found to have an actual material capacity of $13 \mathrm{Mg} \cdot \mathrm{h}^{-1}$. When the actual material capacity of the baler is known, the capacities necessary for wheel loaders and other equipment needed to meet the logistical needs of other large square bale operations can be calculated. The number of wheel loaders needed will be determined by baler material capacity and bale density. Transportation requirements will be a function of the cycle time between field and storage facilities. The rate at which bales need to be loaded and unloaded as well as the distance between the field and storage can be used to determine the size and number of trucks needed.

\section{ACKNOWLEDGEMENTS}

Authors would thank Jaindl Farms and Ernst Conservation Seeds in Pennsylvania for making the field studies possible. We are grateful of $\mathrm{CNH}$ for providing both a large square baler and a field engineer to assist with the switchgrass field baling study. None of the research that took place in fields would have been possible without their support and collaboration. The research was financially supported by Department of Energy (USA) through Northeast Sun Grant Initiatives program.

\section{REFERENCES}

[1] Sokhansanj, S. (2009) Large-scale production, harvest and logistics of switchgrass (Panicum virgatum L.)Current technology and envisioning a mature technology. Biofuels, Bioproducts \& Biorefining, 3, 124-141. doi:10.1002/bbb.129

[2] Prochnow, A. (2009) Bioenergy from permanent grassland-A review: 2. Combustion. Bioresource Technology, 100, 4945-4954. doi:10.1016/j.biortech.2009.05.069

[3] Cundiff, J.S. and Marsh L.S. (1996) Harvest and storage costs for bales of switchgrass in the southeastern United States. Bioresource Technology, 56, 95-101. doi:10.1016/0960-8524(95)00166-2

[4] Sokhansanj, S. and Turhollow A.F. (2004) Biomass densification-Cubing operations and costs for corn stover. Applied Engineering in Agriculture, 20, 495-499.

[5] Kumar, P.K. and Ileleji K.E. (2009) Techno-economic analysis of the transportation, storage, and handling requirements for supplying lignocellulosic biomass feedstocks for ethanol production. ASABE Paper, ASABE, St. Joseph.

[6] Brownell, D.K. (2010) Analysis of biomass harvest, handling, and computer modeling. M.S. Thesis, The Pennsylvania State University, University Park.

[7] Liu, J. and Kemmerer B. (2011) Field performance analysis of a tractor and a large square baler. SAE Paper SAE, Washington DC. doi:10.4271/2011-01-2302 